\title{
CHANGES IN CIVIL-MILITARY RELATIONS SINCE THE FALL OF SUHARTO
}

The Editors

Since our last update, covering the period January 31, 1998-February 1, 1999, the Indonesian military has been center-stage in the country's political transition and undergone a host of structural and personnel changes. For this reason we have decided to publish our regular update in two parts. This first part will mainly address the broad political changes in civil-military relations since Suharto's abdication in May 1998. In the next issue we will publish a second part focusing on internal institutional analysis and a complete data listing on the military elite.

\section{Personnel Changes in the Military Elite}

Over the past nineteen months there have been far-reaching changes in the composition of military elite. From February until October 1999 Gen. Wiranto served as both Coordinating Minister for Politics and Security in the Habibie government and as Commander of ABRI/TNI (Armed Forces of the Republic of Indonesia/Indonesian National Military), giving him vast institutional authority over the military as a whole. Yet, in the face of political change, the unfolding final crisis in East Timor, and escalating regional violence, Wiranto displayed a consistent hesitancy. With the exception of the January 1999 reshuffle of Kodam (Komando Daerah Militar, Regional Military Command) commanders, he made relatively few high-level personnel changes. The officers who served in the military elite during this period were not so much loyal to Wiranto as they were indebted to his failure to push through further, and much needed, personnel changes. 
126 The Editors

The major turning point came in October 1999 with the selection of Abdurrahman Wahid as President. A product of political bargaining, his first cabinet included five generals: Gen. Wiranto as Coordinating Minister for Politics and Security, Lieut. Gen. Susilo Bambang Yudhoyono as Minister of Mines and Energy, Lieut. Gen. Agum Gumelar as Minister for Transportation, Rear Admiral Freddy Numberi as Minister for Administrative Reforms, and Lieut. Gen. (Ret.) Soerjadi Soedirdja as Minister of Home Affairs. In a move approved by Gen. Wiranto, Wahid appointed Juwono Sudarsono, former Deputy Head of the military's National Resilience Institute (Lemhannas) as the country's first civilian Minister of Defense since the 1950s and Admiral Widodo Adi Sucipto (Class 9 1968) as TNI commander, the first ever non-Army officer to command the Indonesian military as a whole.

President Wahid immediately took a series of measures to exert civilian control over the military and rein in the Army. First, he instructed the National Human Rights Commission (Komnas HAM) to investigate military involvement in the atrocities committed in East Timor both prior to and after the August 30, 1999 referendum. Second, he promised prompt solutions to the regional violence in both the Moluccas and Aceh, appointing Vice President Megawati Sukarnoputri to handle the former and taking personal responsibility for the latter. Third, he also made it clear that he supported reform of the military, which was to have important repercussions within the officer corps. Taken together, these moves posed a direct threat to the institutional interests of the military and the personal interests of senior officers.

Under Wahid's government, there have been four major reshuffles of senior personnel. In November 1999, a reshuffle was announced involving more than one hundred senior officers. In February 2000 a second reshuffle moved seventy-four senior officers. In June another 122 senior officers were transferred. Finally, in August yet another, though somewhat smaller, reshuffle was announced. Table 1 (below) shows the timing of senior personnel changes.

It is useful to consider the overall impact of these changes since Abdurrahman Wahid's selection to the Presidency at three levels: TNI headquarters, Army headquarters, and the Kodam command.

With Admiral Widodo's appointment as TNI Commander-in-Chief there has been a significant shift of power at TNI headquarters away from the Army, with the Navy the primary beneficiary. In partial compensation for the Army's loss of the military's top job, Lieut. Gen. Fachrul Razi (Class 10 1970, and an Acehnese) was appointed to the post of Deputy TNI Commander, created in mid-1999 and first held by Admiral Widodo. ${ }^{1}$ Overall, however, of the thirteen tops posts in TNI headquarters, eight are now held by Army officers, four by Naval officers, and one by the Air Force. It is also important to note the graduating classes of these officers. Admiral Widodo and military spokesman Air First Marshall Graito Husodo are 1968 graduates; the graduating classes of the other three naval officers are not known. The Army officers all graduated in 1970, 1971, and 1972.

${ }^{1}$ This post was liquidated on September 20, 2000. 


\section{Table 1}

Timing of Personnel Changes at TNI and Army Headquarters, January 1998 - August 2000

\begin{tabular}{|c|c|c|c|}
\hline & & TNI Headquarters & Army Headquarters \\
\hline \multirow[t]{11}{*}{1999} & Feb. & - & - \\
\hline & Mar. & - & - \\
\hline & Apr. & - & - \\
\hline & May & - & - \\
\hline & June & - & - \\
\hline & July & - & - \\
\hline & Aug. & 1 & 1 \\
\hline & Sept. & - & - \\
\hline & Oct. & - & - \\
\hline & Nov. & 5 & 2 \\
\hline & Dec. & 2 & 1 \\
\hline \multirow[t]{8}{*}{2000} & Jan. & 1 & - \\
\hline & Feb. & - & - \\
\hline & Mar. & 1 & 5 \\
\hline & Apr. & - & - \\
\hline & May & - & - \\
\hline & June & 1 & 6 \\
\hline & July & - & - \\
\hline & Aug. & - & 1 \\
\hline
\end{tabular}

At Army headquarters there has been equally great turn-over of personnel. In December 1999, Army Chief of Staff Gen. Subagyo HS (Class 10 1970), who is reputed to have strong ties to disgraced Lieut. Gen. Prabowo Subianto, ${ }^{2}$ was replaced by his classmate Gen. Tyasno Sudarto. ${ }^{3}$ The appointment of Tyasno was followed by a series of additional personnel changes in the Army high command, first in November, then in March, and again in June. Despite the high turn-over of personnel at Army headquarters, over the past three years there has been no real shift in Army leadership from more senior to more junior classes. Of the eleven top posts, currently four are held by Class 10 1970, four by Class 11 1971, one by Class 12 1972, while two are unknown.

2 Subagyo was also haunted by the scandal over his son, Second Lieutenant Agus Isrok, then serving in Kopassus, who in August 1999 was arrested in a cheap hotel by the West Jakarta police for heroin possession. He was subsequently dismissed from the military and sentenced to eight years in jail.

${ }^{3}$ In July 2000, Tyasno was implicated in a Rp. 19.2 billion counterfeit money ring while serving as Head of Armed Forces Intelligence Body (served Jan. 41999 - Dec. 2 1999), the proceeds of which were allegedly used to pay the pro-Jakarta paramilitaries in East Timor! 
In the case of Kodam commanders it is useful to adopt a slightly longer timeframe, beginning in March 1998, when Gen. Wiranto became ABRI commander-in-chief. Seven Pangdam were replaced between March-May 1998 (Kodams I, III, IV, VI, VII, VIII, and IX). (See Table 2, below.) In July, less than two months after Suharto's abdication, Gen. Wiranto replaced Kodam Jaya (Jakarta) commander Maj. Gen. Sjafrie Syamsudin, a Class 141974 officer and close associate of Lieut. Gen. Prabowo, with Maj. Gen. Djaja Suparman (Class 12 1972), and filled his post as Kodam V Brawijaya (East Java) commander with Maj. Gen. Djoko Subroto (Class 10 1970). All but one of the new appointees were members of Classes 101970 and 11 1971. The January 1999 reshuffle included the appointment of four new Pangdams (Kodams I, IV, V, and VI), with one from Class 11 1971, two from Class 12 1972, and one from Class 141974. Following Abdurrahman Wahid's election as President, yet another major reshuffle was announced, including the appointment of eight new Pangdam. While the command of Kodam Jaya went to Maj. Gen. Ryamizard Ryacudu (Class 14 1974), and that of Kodam VII Wirabuana (Sulawesi) to Maj. Gen. Agus Wirahadikusumah (Class 13 1973), the remaining six appointments (Kodams I, II, III, VIII and IX) went to older officers from Classes 10-12. Finally, between June and August 2000, another seven new Kodam commanders were installed; again (with the exception of newly recreated Kodam XVI Pattimura in the Moluccas) the appointees were all members of older classes-two from Class 10 1970, three from Class 11 1971, and one from Class 12 1972. 
Table 2

Pangdam Appointments by Graduating Class, January 1998 - August 2000

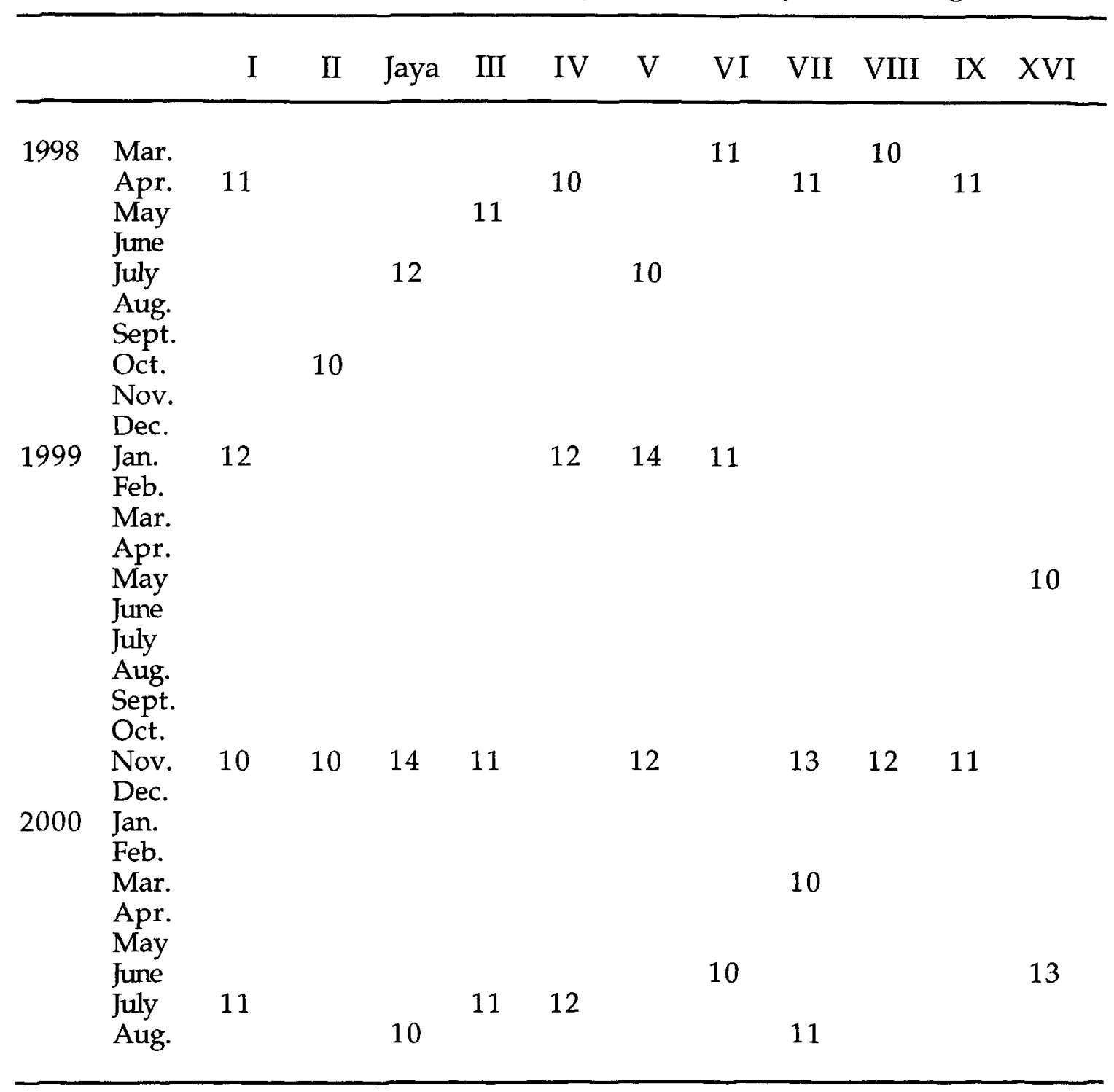

In sum, over the past year, the military elite has been monopolized by officers from Classes 10 1970, 11 1971, and 12 1972. This is remarkable not simply because these officers have dominated the TNI headquarters, Army headquarters, and the Pangdamships, but because over the past six months posts have in fact been passed from junior to more senior officers. Most observers have argued that the June and JulyAugust 2000 reshuffles marked a victory for officers who remain indebted to Suharto, who are loyal to ousted Gen. Wiranto, or who simply oppose reform. While this may be true of individuals, it is not a compelling explanation for its rapid and widereaching personnel changes. Rather, the four reshuffles that have taken place between November 1999 and the present are best understood in terms of a quite different form 
130 The Editors

of internal friction: that between competing classes from the military academy over the far more mundane issue of jobs.

The primary divide seems to lie between members of Classes $101970-121972$, on the one hand, and Class 13 1973, led by Lieut. Gen. Agus Wirahadikusumah, on the other. The members of Classes 10-12 have generally opposed reform because they do not want to be replaced and then, invariably, retired from active duty. On the other hand, Agus and his classmates have generally supported reform because they are wellplaced to benefit from it. In other words, the current friction within the military has probably less to do with politics and more to do with jobs and career prospects. In this light, the November 1999 and February 2000 reshuffles are best seen as benefiting officers who graduated from the Military Academy in 1973 and, secondarily, more junior classes. By contrast, the June and August 2000 reshuffles mark a victory for members of Classes 10 and 11, which now dominate the military (particularly the Army) elite. This has disrupted the natural evolution of the military hierarchy and stalled the promotion of officers from Classes 131973 and 141974.

\section{Regional Violence}

For the Indonesian military, the first real dilemma of the post-Suharto era emerged not in Jakarta but two thousand kilometers away in East Timor. In Dili, Suharto's resignation was greeted by a flowering of pro-independence protest, with students holding a series of free speech fora at the University of East Timor and then carrying the dialogues to district cities and towns. In a desperate game of catch-up, politicians in Jakarta responded to the situation with talk of a "final solution" to the East Timor problem. Already reeling from the loss of eleven officers in a June 6 helicopter crash, the military in East Timor was overwhelmed by the outpouring of protest. In August 1998 , in an attempt to appease the population, Gen. Wiranto announced a highly public withdrawal of several thousand troops (though Fretilin and foreign observers dispute his claim that this withdrawal was actually carried out). Throughout late 1998 widespread protest continued unabated. Kodam IX Udayana (Nusatenggara), Korem 164 (East Timor), Kopassus (Komando Pasukan Khusus, Special Forces Command), and East Timorese collaborators like Governor Abilio Soares responded by deploying existing paramilitary groups and rapidly organizing new ones. ${ }^{4}$

On January 27, 2000, President Habibie announced that he would make a final offer of "broad autonomy" for East Timor at the next tripartite meeting with Portugal and United Nations representatives. Should the proposal for broad autonomy be rejected at the UN, Habibie would recommend to the MPR (People's Consultative Assembly) to "release" East Timor from Indonesia. With the UN and Portugal refusing the offer of broad autonomy, Habibie balked on his plan. Throughout early 1999 discussions continued at the UN, eventually leading to an agreement for a UNsupervised referendum. Although furious at Habibie's offer, the military elite was not

\footnotetext{
${ }^{4}$ For a full account of ABRI and the paramilities in East Timor up until the August 30 referendum, see Douglas Kammen, "The Trouble with Normal: The Indonesian Military, Paramilitaries, and the Final Solution in East Timor," in Violence and the State in Suharto's Indonesia, ed. Benedict Anderson (Ithaca, NY: Cornell Southeast Asia Program, forthcoming).
} 
completely surprised by the announcement. Many officers had come to believe that the government would seek a political solution to the East Timor problem. As bad as the pre-referendum violence was, the August 30 referendum and subsequent atrocities committed by the TNI and its paramilitaries in East Timor were devastating for the military. Internationally, TNI came under immediate and intense condemnation. While the nationalist backlash in Indonesia against what was viewed as foreign interference and national humiliation was to soften the blow, TNI had suffered a humiliating defeat, with repercussions for its political standing at home. When the US called on the military to end the violence and punish those responsible, Gen. Wiranto responded with the extraordinary comment that he would have to "negotiate" with the boys in the field, indicating in no uncertain terms that he and military headquarters were not in control of the situation.

East Timor was not the only place where the military found itself facing regional violence. In Aceh, two decades of misrule and military atrocities, combined with the example of the successful East Timor referendum, fueled support for the Gerakan Aceh Merdeka (Free Aceh Movement, GAM) and calls for independence. Unwilling, and probably incapable or unable, to respond with a massive military onslaught, and reluctant to tarnish its image further, the TNI withdrew a number of battalions in August-September 1998..$^{5}$ In their place, the Mobile Brigade (Brimob) and the Police were ordered to secure order in the province, a task for which they were wholly unsuited. Finally, after months of negotiation, in May, the TNI took the highly unusual step of signing a three-month cease-fire with GAM. However, this move, which was intended to undermine support for independence, angered pro-independence hardliners and led to an escalation of gangster-style violence in the province.

In Irian Jaya, Suharto's fall was greeted with popular protest and renewed calls for the creation of an independent Papua Barat. On July 6, 1998, unidentified military units opened fire on one such demonstration in Biak and threw the dead into the sea. When some bodies were later washed up on shore, the military claimed that they were victims not of the massacre but of the devastating tsunami that hit the coast of Papua New Guinea on July 17. A month later, coincident with the highly publicized pull-out of troops from East Timor, the military withdrew several Kostrad (Komando Strategis Angkatan Darat, Army Strategic Command) battalions posted in Irian Jaya as part of the Rajawali III operational campaign. ${ }^{6}$ Nevertheless, the military presence in Papua, as the province was renamed, has remained high, with Kopassus personnel posted at district-level Kodim headquarters especially conspicuous.

The outbreak of sectarian violence in the Moluccas in early 1999 escalated over the course of the next eighteen months. In late 1999 President Wahid assigned Vice President Megawati Sukarnoputri to resolve the conflict, primarily because the strong showing of her party (PDI-P, Indonesian Democratic Party of Struggle) there in the June election demonstrated that Megawati enjoyed support from both Christians and

\footnotetext{
5 This included territorial infantry battalions 121 (Tebing Tinggi), 122 (Pematang Siantar), 126 (Kisaran), 132 (Bangkinang, Riau), 133 (Padang Panjang), and Kostrad battalions 328 (Bogor) and Armed 10/76 (Bogor); in November 1999 additional troops from infantry battalions 100 (Langkat), 131 (Payakumbuh), 133 (Padang Panjang), and Kostrad 328 (Bogor) were also withdrawn.

6 These included Kostrad battalions 303 (Garut), 330 (Bandung), 411 (Salatiga), 412 (Purworejo), and 515

(Tanggul, Jember), as well as territorial Battalion 712 (Manado).
} 
Muslims. Megawati, however, showed little interest in the Moluccas and the violence spread. The TNI, however, responded with an extraordinary troop build-up. There are currently at least fifteen different external battalions posted there, comprised of eight thousand Army troops and four hundred from the Mobile Brigade. Though sent to restore order, it has become clear that a number of these military and police units have taken sides, deepening the conflict even further. Finally, President Wahid declared a state of Civil Emergency beginning June 27.

There are an increasing number of people, including some in the government, who believe that the military is fueling regional violence as part of a broader attempt to maintain, or even increase, its socio-political role, and there have been suggestions that this is part of a strategy to seize power. There is little evidence to support such a conclusion, however, and a host of reasons to think that this is not the case. Rather, TNI now finds itself facing (and being implicated in) conflicts that it is militarily incapable of winning and from which it is politically unable to extricate itself. The loss of East Timor and ongoing violence in Aceh, Irian Jaya, the Moluccas, and now Central Sulawesi have stretched the Army's combat units extremely thin. Furthermore, members of the military elite have repeatedly denied responsibility for major human rights abuses, allowing lower-level officers to take the fall. This cowardice has devastated morale among junior and non-commissioned officers, weakened the chain of command, and led to increased desertion, both in provinces racked by armed conflict and elsewhere.

\section{Structural Changes}

In May 1999, Minister of Defense Gen. Wiranto announced that there would be a phased return to the pre-1980s system of seventeen Kodam, in accordance with the "new defense paradigm" designed to ensure that the Kodam are closer to the populace. The first such move was taken with the creation of Kodam XVI Pattimura (Moluccas) on May 15, 1999.7 There was discussion about when the other six Kodam would be established, but no time table was set. ${ }^{8}$ The primary reason for the return to the old system of seventeen Kodam was not that it would enable the military to make a better response to local violence nor that the military saw the chance as a means of strengthening its political position. Rather, the return to the old system would allow for the creation of new posts and hence additional jobs, something badly needed to accommodate the bloated size of the officer corps and to offset the loss of jobs caused by the abolition of kekaryaan-the secondment of active-duty officers to the civil service, local legislatures, and regional executives. Despite the military announcement,

\footnotetext{
7 The first Pangdam XVI and his successor both held the rank of brigadier-general, not major-general, as in the other ten Kodam, reflecting the differential status that had existed prior to Murdani's 1985 reorganization of the territorial structure and the lower status of the new Kodam.

${ }^{8}$ In September 1999 there were also reports that Korem 161 Wirasakti (Kupang) would be upgraded to the status of Kodam, presumably to shore up defense along the East Timor and Australian borders, and perhaps too as a means of accommodating officers and troops from the defunct Korem 164 Wiradharma (East Timor). "Korem 161/Wirasakti NTT Dijadikan Kodam," Media Indonesia, September 29, 1999. Note that under the pre-1985 system all of Nusatenggara was part of a single Kodam (IX), not two as proposed by Gen. Wiranto.
} 
the vociferous local outcry over such plans in Flores and elsewhere makes it highly unlikely that the expansion of the Kodam will take place.

Despite these plans, the territorial structure has been affected by two competing developments. On the one hand, in accordance with the "territorial doctrine," the establishment of new administrative units, particularly Kabupaten, has allowed the corresponding creation of new Kodim. On the other hand, in April 2000 the military announced the trial abolition of the Babinsa (military presence at the village-level) and subdistrict-level Koramil, the lowest rungs of the territorial structure, in Kodam Jaya (Jakarta) and in Surabaya under Kodam Brawijaya (East Java)..$^{9}$ Nevertheless, there has not been any reporting on actual liquidations; instead, it appears that the Babinsa and Koramil have simply been redefined as part of the local Kodim. In sum, over the past year there has been both a push for expansion and a pull for reduction in the territorial structure. Small as these steps may appear, the resolution of the problem of the territorial doctrine and structure is perhaps the single most crucial determinant of the future political position of the military.

In May 2000, Minister of Defense Juwono Sudarsono announced plans to abolish the position of TNI Commander-in-Chief (Panglima TNI), and replaced it with a Chief of the Joint Staffs (Kasgab-Kepala Staf Gabungan TNI). The new post would no longer have ministerial rank, but be placed under the Minister of Defense. ${ }^{10}$ The TNI leadership has also proposed that the position of Kasgab TNI be rotated between the three service branches at regular three year intervals, though this proposal remains to be discussed with the national legislature. "Rotating the position," according to Minister Juwono, "will prevent one service branch from feeling left out."11 Three months later, at the August meeting of the MPR, a new bill was passed requiring that the selection of a TNI Commander be approved by the People's Representative Council (Dewan Perwakilan Rakyat, DPR) and granting the Vice President the right to play a role in military appointments (a crucial decision to which we will return).

After more than a year of discussion, on July 1, 2000, the national police was separated from TNI and placed directly under the president's control. Plans were also announced to increase its current size of roughly 200,000 to about 300,000, and to replace the existing military-style ranks with standard international police ranks, in order to improve the police's image. For TNI the separation means a loss of budget, but it also allows the military to free itself of some of the least desirable tasks and responsibilities; as seen in the handling of Aceh over the past year.

On March 8, in a surprise move, President Wahid signed two new Presidential Decrees, one abolishing Bakorstanas, the National Stabilization and Coordination Board, the other ending the Special Background Check, Litsus, required of all civil servants. ${ }^{12}$ Though the central secretariat in Jakarta had its own staff, it is necessary to

\footnotetext{
9 There are, to our knowledge, no Babinsa in either city. Reported in "Proyek Percontohan Komando Teritorial," Sena, May-June 2000, p. 62.

10 "Juwono soal Rencana Perombakan Struktur Militer: Panglima TNI Digusur, Diganti Kasgab," Jawa Pos, May 23, 2000.

11 "Jabatan Kasgab Digilir Tiap 3 Tahun," Suara Merdeka, June 2, 2000.

12 Bakorstanas was established by Presidential Decree No. 29.1988, replacing the former Kopkamtib. The Litsus requirement was enacted by Presidential Decree No. 16/1990.
} 
note that at the provincial level Bakorstanas was never an independent institution; it was primarily staffed by officers from the territorial military commands, with only a small number of full-time officers, and essentially served as a "spook" with which to threaten repression. ${ }^{13}$ Litsus has allowed the military to reject the appointment of civilians deemed to have "unclean" backgrounds, and hence to justify the continued appointments of military personnel to the civil service. Both Minister of Defense Juwono Sudarsono and TNI Commander-in-Chief stated that they were not aware that there were plans to abolish either Bakorstanas or Litsus, but that they accepted the president's decision.

Another surprise in March 2000 was the announcement that Kopassus (Komando Pasukan Khusus, Special Forces Command) would be reduced in size. This announcement stirred considerable confusion, apparently initiated by a report in The Sydney Morning Herald that Kopassus was to be slashed from six thousand to a mere seven hundred troops. Minister of Defense Juwono Sudarsono quickly denied this: "That is not true. The truth is that [Kopassus] will be cut from about six thousand troops to a little over five thousand, a reduction of seven hundred personnel. It wouldn't be possible to reduce personnel from six thousand to seven hundred in only one year."14 This signaled an important roll-back of the expansion carried out under Prabowo Subianto's tenure as Commander of Kopassus from late 1995 until early 1998. Yet, a week after the announcement, Kopassus Commander Maj. Gen. Syahrir said that he had "not yet received orders" to carry out the reduction. ${ }^{15}$ Since then, there has been no further reporting on this issue and the outcome remains unclear.

At the same time, the military has also announced plans to review the size of combat forces in all three service branches and to implement expansions. Over the next ten years the Marine Corps will be expanded from its current two brigades (stationed in Surabaya and Jakarta) with a total of thirteen thousand personnel to three brigades (the third to be based on Rate Island, Lampung) with a total of 23,000 personnel. ${ }^{16}$ The Air Force Special Force (Pasukan Khas AU) will be increased from six squadrons to ten, with Kupang, West Timor, singled out as the single most important location for this expansion. ${ }^{17}$ And, on a visit to Kostrad Division I headquarters in Cilodong, Bogor, President Wahid announced that Kostrad would also be expanded, though no details were provided. ${ }^{18}$ These announcements are in part an attempt to appease the military over the changing status of civil-military relations, in part too a matter of providing jobs for excess officers.

${ }^{13}$ In East Java, for example, the provincial Bakorstanasda was limited to fourteen members, including: Pangdam V/Brawijaya, the Chief of Staff of Kasdam V, the regional naval commander (Pangarmatim), the provincial chief of police, the Governor, and the provincial-level state prosecutor, with university rectors serving as associate members. "Bakorstanasda Dibubarkan, Pangdam V Minta Maaf," Surabaya Post, April 5,2000 . According to one report, the liquidation of Bakorstanas resulted in a loss of jobs for 271 colonels and three officers of general rank. "Kelompok Cilangkap Dominan," Media Indonesia, June 11, 2000.

14 Quoted in "Personel Kopassus Akan Dirampingkan," Suara Merdeka, March 21, 2000.

15 "Danjen belum Dapat Instruksi Pengurangan Anggota Kopassus," Republika, March 31, 2000.

16 "Korps Marinir akan Dikembangkan Jadi Tiga Brigade," Republika, December 9, 1999.

17 "Pasukan Elit AU Juga Dimekarkan," Riau Post, April 10, 2000.

18 "Presiden akan Mekarkan Kostrad dan Polri," Republika, April 28, 2000. 
The separation of the police, the expansion of combat units, and President Wahid's call for a stronger military raised budgetary questions. In December 1999, soon after assuming his post as Minister of Defense, Juwono Sudarsono announced a 62 percent increase in the military budget from Rp. 11.6 trillion to Rp. 18.9 trillion per year, with Rp. 9.12 trillion earmarked for equipment and Rp. 5.45 trillion for salaries. ${ }^{19}$ Overall, however, it is essential to note that the vast majority of these announced changes in the military structure and strength have not yet been implemented and time tables have not been made public. Again, it remains to be seen if the military leadership is willing to push through reforms that it knows are unpopular with the officer corps and troops, and if local commanders will engage in foot-dragging or outright resistance to central directives.

\section{Civil-Military Friction}

The personnel reshuffles and structural changes discussed above have been punctuated by a series of highly public and embarrassing military scandals. These scandals have all reflected tensions along two lines: tensions between the president and TNI over the redefinition of civil-military relations, and between pro-status quo officers from senior military classes and pro-reform officers from more junior classes. More interestingly, these scandals have also highlighted a series of institutional dilemmas facing the military regarding structural reform, personnel appointments, and budgetary constraints.

Soon after being elected President, Wahid invited outspoken Maj. Gen. Agus Wirahadikusumah, nephew of former Vice President Umar Wirahadikusumah and a 1973 graduate of the military academy, to Jakarta for discussions. Taking Wahid's selection as president as a sign favorable to further reform and the invitation as encouragement, Agus issued repeated calls for the liquidation of the military's territorial structure. Senior officers at both TNI and Army headquarters viewed this as a challenge to the chain of command and a threat to their authority. Kostrad commander Lieut. Gen. Djaja Suparman (Class 12 1972) responded angrily by declaring that attacks on the officer corps would anger the military as a whole, including troops. Agus shot back: "The soldier's loyalty is to the institution, to the nation, and to the state, not to the generals. Our soldiers are not soldiers of hulubalang, nor soldiers of generals, and also not hulubalang of the regime." 20 The public nature and harshness of the extended exchange prompted the TNI commander-in-chief to issue a public statement that TNI was not divided: "You [reporters] are the ones saying there is a difference of opinion. [But] There's no difference of opinion in TNI."21 To demonstrate unanimity, Widodo held a commander's call three days later at TNI headquarters in Cilangkap, East Jakarta, attended by 160 senior officers from all three service branches.

\footnotetext{
19 "Anggaran Militer Naik 62\%," TNI Watch!, December 15, 1999.

20 See "Pangdam Wirabuana Tanggapi Pernyataan Pangkostrad: 'Prajurit bukan Hulubalang Jenderal," Media Indonesia, December 17, 1999. Hulubalang were the "officers" of precolonial Sumatran and Malay rulers, mercenaries, raja family members, or local aristocrats, and the term has connotations of feudalism and warlordism (i.e. the opposite of professionals).

21 "Laksamana Widodo AS: TNI tidak Pecah," Media Indonesia, December 21, 1999.
} 
136 The Editors

Soon after the Agus-Djaja exchange, rumors spread about a planned military coup. This rumor not only caused a domestic stir, but also renewed international concern about the political position of TNI, with US ambassador to the UN, Richard Holbrooke, issuing a warning to the military against such a move. The TNI publication Sena ran a front-page article calling the rumor "slander" (fitnah) and quoting military spokesman Maj. Gen. Sudradjat as saying: "I think the TNI knows more about the TNI than Ambassador Holbrooke. We hope that people outside of Indonesia will not meddle in Indonesia's domestic affairs." MPR speaker Amien Rais added that "however bad the TNI leaders may be, none of them dare [to attempt a coup]. It would be the same as suicide." 22 There was no coup, of course. This did not mean that military personnel remained united or approved of the ongoing changes, but rather reflected the simple fact that the military elite was devoid of forceful leadership and deeply aware of its unpopularity. More importantly, the rumor was a clear indication that members of the military elite were unhappy with presidential meddling in what they viewed as internal matters and displeased by Wahid's open praise for reformminded Agus Wirahadikusumah.

President Wahid responded to the rumors by staging a new series of attacks against the military elite. In early 2000 , he repeatedly recommended that Wiranto resign from his post as Coordinating Minister for Security and Politics and focus his attention on the accusations over his responsibility for the East Timor atrocities. ${ }^{23}$ Wiranto, however, immediately refused to do so. Stepping up pressure, the president suspended Wiranto from his post in early February and appointed Minister of the Interior Lieut. Gen. (Ret.) Soerjadi Soedirdja as an interim replacement. Finally, on May 19 Wiranto was forced to resign. The case highlighted the tensions in developing civilmilitary relations: where Wahid believed that a voluntary resignation would minimize resentment by the military, Wiranto's intransigence over three months had the opposite affect.

During the same period, President Wahid made repeated public statements about there being a coterie of disloyal officers, especially among the Kodam commanders. "I know that there are a couple of Pangdam who are gathering forces to undermine [mreteli] my government. But I don't care." 24 A day later, Wahid suggested that these officers had in fact held a meeting: "I could tell you the hotel, the time, who was present, and what they discussed. I dare to speak like this because I have proof."25 Media analysis focused on Kodam V Brawijaya (East Java) commander Maj. Gen. Sudi Silalahi (Class 12 1972). But according to sources in TNI headquarters, President Wahid's comments were directed at Kodam III Siliwangi (West Java) commander Maj.

22 "Tidak Ada Pikiran TNI Lakukan Kudeta," Sena, January-February 2000, pp. 31-33.

23 In early February, while visiting the Vatican, Wahid offered the fantastic story that Suharto had once told ABRI Commander Gen. Feisal Tanjung to order Wiranto (then Kostrad commander) to "disappear" both Wahid and Megawati Sukarnoputri, but that Wiranto had informed Wahid, who then confronted Suharto directly. Reported in "Gus Dur Buka Rahasia Wiranto," Riau Pos, February 7, 2000.

24 The original statement: "Saya tahu kok, beberapa pangdam mengumpulkan kekuatan untuk mreteli pemerintahan saya, tapi saya cuek saja." Quoted in "Sejumlah Pangdam Ingin Goyang Saya,"Banjarmasin Post, March 15, 2000.

25 "Pangdam Jelek, Out Saja," Banjarmasin Post, March 18, 2000. 
Gen. Slamet Supriyadi (Class 11 1971) and Kodam IV Diponegoro (Central Java) commander Maj. Gen. Bibit Waluyo (Class 12 1972). ${ }^{26}$

In June yet another military scandal emerged. Reports appeared that a group of officers had gathered at the home of Lieut. Gen. Agus Wirahadikusumah, located in the Senior Army Officers Housing complex in Bulakrantai, South Jakarta, on April 16, and once again thereafter. A month later a four-page document began to circulate offering an analysis of the forces loyal to Wiranto and Kostrad commander Djaja Suparman, and of the ways to accelerate the rise of Agus Wirahadikusumah to the post of army chief-of-staff. ${ }^{27}$ According to sources in TNI headquarters, officers from Classes 10 1970-12 1972 politicized what was a regular social event (selamatan) at the home of Lieut. Gen. Agus Wirahadikusumah as being a political meeting and someone (perhaps from outside the military) circulated a fake document to discredit Agus. The faked document served its purpose: in the June reshuffle Brig. Gen. Saurip was removed from his post and plans were made for a further reshuffle later in the year in which Agus would lose his post as Kostrad commander.

\section{Looking Ahead}

Looking ahead, the future role of the TNI will hinge on the resolution of three major issues. The first of these has to do with the relationship between the territorial and combat structures/units. As discussed above, the doctrine of territoriality, dating from the guerrilla struggle against the Dutch, has come under pressure from four different directions: (1) reform-minded officers have called for its outright abolition; (2) the military elite has announced the trial liquidation of the two lowest rungs (Babinsa and Koramil); (3) the military elite has also announced plans to expand the existing eleven Kodam to seventeen; and (4) the creation of new administrative units (particularly Kabupaten) is allowing the establishment of new parallel military units. Any move to alter the territorial structure, particularly reduction, will likely heighten tensions between territorial commands and the existing combat commands (Kostrad, Kopassus, the Mobile Brigade, etc.). On the one hand, significant alteration in the territorial structure will push more officers into the "combat" forces. On the other, primary responsibility for social order will also likely shift to these combat units, placing them in a more prominent and less enviable political position. Both of these tensions were apparent in East Timor in 1998-99, and now also in the Moluccas.

The second major issue concerns the changing character of the Army officer corps. The officers now dominating TNI headquarters, Army headquarters, and the eleven Pangdamships are all members of the large classes that graduated from the military academy during the early 1970s. Their monopolization of senior posts has prevented the rise of more junior classes, with Class 131973 the primary victim. It thus remains to be seen if Class 131973 and Class 141974 will be given the opportunity to hold top posts or, as was the case with Classes 41964 and 5 1964, will be bypassed. For

\footnotetext{
26 Both were removed from their posts in July 2000, with Slamet Supriyadi nominated to serve as a DPR member and Bibit Waluyo moved to head the Army Staff and Command School (Seskoad).

27 The document also listed those present, including: Agus himself, Army Assistant for Territorial Affairs Maj. Gen. Saurip Kadi, Kodam Jaya Chief of Staff Brig. Gen. Simbolon, Lieut. Col. Baktiman, State Secretary Bondan Gunawan, Rahman Tolleng, Prof. Frans Magnis Suseno, and several student and NGO activists.
} 
beginning in 1976, the size of classes graduating from the Military Academy in Magelang dropped (for reasons that remain unclear) to under one hundred per year (a 75 percent reduction from the four hundred officers per year graduated during the early 1970s). These small classes from the late 1970 s and early 1980 s have already achieved a remarkable degree of prominence and appear poised to move into the general ranks over the next several years. The political stance and military judgment of these officers remains obscure. One imagines, however, given their excellent career prospects, that these officers will be politically conservative, preferring almost assured career success over political adventurism. But in the face of heightened regional violence and economic constraints, these officers may find themselves at odds with the troops they command and the local officials with whom they must work.

The third and most important issue facing TNI remains the ongoing struggle to redefine civil-military relations. In plain terms, what will civilian supremacy over the military mean in a nominally democratic Indonesia? At present there is a great degree of confusion over this issue. Although he has not addressed the problem explicitly, President Wahid appears to believe that "civilian supremacy" means civilian control over not only the policy process, but also of the appointment of military personnel. Others have argued persuasively that this view will only upset the orderly appointment and promotional process and anger the military as an institution. Nurcholis Madjid and others have recommended that civilian supremacy be restricted to the policy process, while granting TNI internal autonomy in personnel matters.

Postscript: As we are going to press, Army Chief of Staff Gen. Tyasno Sudarto has been replaced by Gen. Endriartono Sutarto (Class 11 1971), and Navy Chief of Staff Admiral Achmad Sucipto has been replaced by Admiral Indroko Sastrawiryono (1971). 